\title{
Identification of active compounds and antioxidant activity of teak (Tectona grandis) leaves
}

\author{
VENTY SURYANTI", TRIANA KUSUMANINGSIH, SOERYA DEWI MARLIYANA, HILDA ALFIANI SETYONO, \\ ELYNA WAHYU TRISNAWATI \\ Department of Chemistry, Faculty of Mathematics and Natural Sciences, Universitas Sebelas Maret. Jl. Ir. Sutami 36A, Surakarta 57126, Central Java, \\ Indonesia. Tel./fax.: +62-271-663375, vemail: venty@ mipa.uns.acid
}

Manuscript received: 30 December 2019. Revision accepted: 6 February 2020.

\begin{abstract}
Suryanti V, Kusumaningsih T, Marliyana SD, Setyono HA, Trisnawati EW. 2020. Identification of active compounds and antioxidant activity of teak (Tectona grandis) leaves. Biodiversitas 21: 946-952. Teak (Tectona grandis) grows in tropical area and the teak wood is widely used for building construction and furniture. Young teak leaf contains red pigment and often are used for natural food coloring. The research objectives were to isolate the young teak leaf chemical compounds and to investigate their antioxidant activities. The compounds identification was carried out by UV-Vis Spectroscopy, GC-MS and LC-MS. The antioxidant activity determination was carried out by 2,2-diphenyl-1-picryl-hydrazyl-hydrate (DPPH) method. The total phenolics content was determined using Folin-Ciocalteu method and total anthocyanins content was examined using the H-differential method. Two fractions were observed further by UV-Vis Spectroscopy, GC-MS and LC-MS. The UV-Vis spectrum of $F_{A}$ confirmed the presence of anthocyanins which has maximum absorbance at 208 and $492 \mathrm{~nm}$. The GC-MS spectrum of fraction A ( $\left.\mathrm{F}_{\mathrm{A}}\right)$ revealed 4-hydroxy-4-methyl-2pentanone, glycerin monoacetate, glycerin diacetate and 1-eicosanol. The UV-Vis spectrum of $F_{C}$ also confirms the presence of anthocyanins which has maximum absorbance at $489 \mathrm{~nm}$. The LC-MS spectrum of fraction $\mathrm{C}\left(\mathrm{F}_{\mathrm{C}}\right)$ shows anthocyanins, namely malvidin-3-o- (6-o-acetyl)-5-o-diglucoside. The $\mathrm{F}_{\mathrm{A}}$ and $\mathrm{F}_{\mathrm{C}}$ teak leaf fractions have strong antioxidant activities as their $\mathrm{IC}_{50}$ values are less than $50 \mathrm{ppm}$. Total phenolic of teak leaf extract was $6.17 \mathrm{mg}$ GAE/g and total anthocyanins of teak leaf extract were $67.5 \mathrm{mg} / \mathrm{L}$.
\end{abstract}

Keywords: Antioxidant activity, teak leaves, Tectona grandis, total anthocyanins, total phenolics

\section{INTRODUCTION}

Tectona grandis (teak) belongs to Eukaryota domain, Plantae kingdom, Spermatophyta phylum, Angiospermae subphylum, Dicotyledonae class, Lamiales order, Verbenaceae family and Tectona genus. Teak is a tropical plant species distributed in the countries of Indonesia, India, Thailand, Nigeria, and Myanmar (Ogunmefun et al. 2017). Teak cultivation in Indonesia has a total area of 923.92 ha (Hermawati et al. 2015). Teak wood is extensively used for building construction and furniture and teak leaves are widely used as food wrapping and as natural food dye. Teak leave is also widely used in Asia for the treatment of diabetes, inflammation, bronchitis, cancer, skin diseases, malaria and TBC (Rajuri et al. 2010).

Teak leaves content secondary metabolites such as flavonoids, alkaloids, tannins, anthraquinones, naphthoquinone, anthocyanins and cyanidins which have various activities, such as antibacterial, antitoxic and antioxidant activity (Murukan and Murugan 2018a, Murukan and Murugan 2018b, Murukan and Murugan 2018c and Arief et al. 2014). The green young teak leaves turn to brownish-red color when they are ripped. The released color indicates the young teak leaves contain anthocyanins since anthocyanins give red, orange, purple, blue to black colors (Du et al. 2015). The green young teak leave also contains tannins as indicating by sticky sap of leaves. Tannin and phenolic compounds, such as anthocyanins possess antioxidant activities (Kutlu et al. 2011 and Arief et al. 2014). The use of compounds rich in antioxidant activities is growing rapidly both for food and medicines (Hanani et al. 2005). The common antioxidants used in food are synthetic antioxidants. The use of synthetic antioxidants should be very limited and be avoided because they can be carcinogenic. Therefore, the use of natural antioxidants is growing for safety reasons (Ghany 2015).

Kopa et al. (2014) isolated compounds from teak leaves by extraction using methanol, water, and ethyl acetate, followed by purification by Sephadex LH-20 column chromatography. Murukan dan Murugan (2017) isolated teak leaves compounds by extraction using methanol containing $0.5 \% \mathrm{HCl}$, followed by liquid-liquid extraction using ethyl acetate and column chromatography using Amberlite XAD-7. Murukan dan Murugan (2018b) isolates teak leaves compounds by extraction using methanol containing $1 \% \mathrm{HCl}$ then continued by liquid-liquid extraction with ethyl acetate and chloroform, and finally by Amberlite XAD column chromatography. Baharuddin et al. (2015) isolate the teak leaves compounds by extraction using methanol which was then followed by Liquid Vacuum Chromatography (LVC). Arief et al. (2014) had extracted teak leaves compounds with ethanol which was applied for sausage meat. Lismawenning et al. (2013) had extracted young teak leaves with water and applied it to the glass. Qadariyah et al. (2018) extracted teak leaves by 
ultrasonic method with ethanol $60 \%$ and water as solvents and applied it to the fabric. Although the isolation of teak leave compounds has been performed, however, information on diversity of the teak leaves compounds is still limited. Therefore, this study focuses on the identification of antioxidant active compounds from teak leaves.

\section{MATERIALS AND METHODS}

\section{Materials}

The first three young leaves were harvested from teak plant in Boyolali, Jawa Tengah, Indonesia. Gallic acid and 2,2-diphenyl-1-picrylhydrazyl (DPPH) were obtained from Sigma Aldrich. The other chemicals used were purchased from E-Merck and the solvents used were analytical grade without further purification.

\section{Sample preparation}

Young teak leaves were cut into small pieces and dried by aerating at room temperature. Then, the dried young teak leaves were ground to fine powder. The dried powder of young teak leaves $(1 \mathrm{~kg})$ was macerated using methanol ( $5 \mathrm{~L})$ with presence of $1 \%$ HCL solution. The extract was then evaporated using rotary evaporator to get methanol extract $(20 \mathrm{~g})$.

\section{Fractionation by Liquid Vacuum Chromatography (LVC)}

The methanol extract (15 g) was separated into fractions based on the polarity of the compounds. Impregnation sample was carried out before the separation process by LVC using silica gel $60(0.2-0.5 \mathrm{~mm})$ Merck as a stationary phase. The eluent used was a mixture of hexane and ethyl acetate with a ratio of $4: 6,2: 8$ and $0: 10$ in total volume of 300,450 and $1500 \mathrm{~mL}$ respectively.

\section{Fractionation by Gravity Column Chromatography (GCC)}

The extract obtained from LVC was introduced into the packed column of $20 \mathrm{~g}$ silica gel $60(0.063-0.200 \mathrm{~mm})$ Merck. A polarity gradient was used for mixtures of hexane and ethyl acetate with the ratio of 9:1, 8:2, 7:3, 6:4, 5:5, 4:6 and $0: 10$ in total volume of $50 \mathrm{~mL}$. Eluent was collected in a test tube and analyzed by thin-layer chromatography (TLC). The eluted fractions with similar spots or $R_{f}$ values were collected and concentrated using rotary vacuum evaporator.

\section{UV-Vis Spectroscopy}

The UV-Vis analysis with wavelength of $800-200 \mathrm{~nm}$ was performed for fraction $\mathrm{A}\left(\mathrm{F}_{\mathrm{A}}\right)$ and fraction $\mathrm{C}\left(\mathrm{F}_{\mathrm{C}}\right)$ using acetone as solvent with Perkin Elmer Precisely Lambda 25 UV-Vis.

\section{Gas Chromatography-Mass Spectroscopy (GC-MS)}

The $F_{A}$ was analyzed by Shimadzu QP2010S GC-MS. The GC-MS was run using EI 70 Ev ionizing type, Rtx 5 Ms column type which has column length of $30 \mathrm{~m}$ and diameter $0.25 \mathrm{~mm}$, column temperature of $70^{\circ} \mathrm{C}$, injector temperature of $300^{\circ} \mathrm{C}$, splitless injection method, detector temperature of $300^{\circ} \mathrm{C}$ and carrier gas $\mathrm{He}$ of $13.7 \mathrm{kPa}$.

\section{Liquid Chromatography-Mass Spectrometry (LC-MS)}

The $\mathrm{F}_{\mathrm{C}}$ was analyzed by LC-MS Waters 2489 with UVVis detector. The column temperature was $35^{\circ} \mathrm{C}$ and the solvent used was a mixture of solution A (aquadest: formic acid = 9: 1) and solution B (aquabidest: acetonitrile: formic acid = 6: $3: 1$ ) with a flow rate of $1 \mathrm{~mL} / \mathrm{min}$ for 25 minutes. The solvents gradient used for the initial 5 minutes was $75 \%$ solution $\mathrm{A}$ and $25 \%$ solution $\mathrm{B}$, the next 5 minutes was $71 \%$ solution $\mathrm{A}$ and $29 \%$ solution $\mathrm{B}$, the next 5 minutes was $66 \%$ solution $\mathrm{A}$ and $34 \%$ solution $\mathrm{B}$, the next 5 minutes was $62 \%$ solution $\mathrm{A}$ and $38 \%$ solution B, $57 \%$ A and $43 \%$ solution B, last 5 minutes was $100 \%$ solution B. The absorbance of ultraviolet was measured at $520 \mathrm{~nm}$. MS analysis was used ESI ionization.

\section{Determination of total phenolics}

The total phenolics determination was performed according to Doymaz and Karasu (2018) with slight modification. Gallic acid solution ( $1 \mathrm{~mL}$ of $10 \mathrm{ppm}$ ) was put into a $5 \mathrm{~mL}$ volumetric flask, then was added $0.5 \mathrm{~mL}$ of Folin-Ciocalteu reagent and left for 1 minute. The mixture was then added $3.5 \mathrm{~mL}$ of $7.5 \% \mathrm{Na}_{2} \mathrm{CO}_{3}$ and was left for 1 minute. The samples were measured using UV-Vis Spectroscopy at 10 minutes intervals until reaching equilibrium state. Standard curves of gallic acid with concentrations of $2,4,6,8,10 \mathrm{ppm}$ were treated with the same method to determine the quantitative of total phenolics. Total phenolics test was carried out for $100 \mathrm{ppm}$ extract samples. The extract sample $(1 \mathrm{~mL})$ in $5 \mathrm{~mL}$ volumetric flask was added Folin-Ciocalteu $(0.5 \mathrm{~mL})$ and left for 1 minute. The mixture was then added with $3.5 \mathrm{~mL}$ of $7.5 \% \mathrm{Na}_{2} \mathrm{CO}_{3}$ and left for the maximum time before the absorbance value was measured. Total phenolics was calculated using equation (1), where $\mathrm{C}=$ concentration of gallic acid established from the calibration curve $(\mathrm{mg} / \mathrm{ml})$, $\mathrm{V}=$ volume of extract $(\mathrm{mL})$ and $\mathrm{m}=$ weight of the plant extract $(\mathrm{g})$.

$$
\text { Phenolics Total }(\mathrm{mg} \mathrm{GAE} / \mathrm{g})=\frac{\complement W}{\mathrm{~m}}
$$

\section{Determination of total anthocyanins}

Total anthocyanin test was completed according to Lee et al. (2005). Teak leaf extract (50 mg) in $\mathrm{HCl}-\mathrm{KCl}$ buffer solution $\mathrm{pH} 1(4 \mathrm{~mL})$ and teak leaf extract $(0.05 \mathrm{~g})$ in $\mathrm{CH}_{3} \mathrm{COOH}-\mathrm{CH}_{3} \mathrm{COONa}$ buffer solution $\mathrm{pH} 4.5$ (4 mL) were left for 2 hours. The absorbance was measured at 520 $\mathrm{nm}$ and $700 \mathrm{~nm}$. Total anthocyanins was calculated using equation (2), where $A=\left(A_{520 n m}-A_{700 n m}\right) p H 1.0-\left(A_{520 n m}-\right.$ $\left.\mathrm{A}_{700 \mathrm{~nm}}\right) \mathrm{pH} 4.5, \mathrm{MW}=$ molecular weight of the cyanidin-3glucoside $(449.2 \mathrm{~g} / \mathrm{mol}), \mathrm{DF}=$ dilution factor, $\varepsilon=$ molar extinction coefficient $(26,900 \mathrm{~L} / \mathrm{mol} . \mathrm{cm})$ and $1=$ cell path length $(1 \mathrm{~cm})$.

Total Anthocyanins $(\mathrm{mg} / \mathrm{L})=\frac{\mathrm{A}}{\varepsilon \times \mathbb{I}} \times \mathrm{Mw} \times \mathrm{DF} \times 1000 \ldots$ 


\section{Determination of antioxidant activity}

The antioxidant activity determination was performed according to Salazar-Aranda et al. (2011). Teak leaf extract $(5 \mathrm{mg}), \mathrm{F}_{\mathrm{A}}(5 \mathrm{mg}), \mathrm{F}_{\mathrm{C}}(5 \mathrm{mg})$ or vitamin $\mathrm{E}(5 \mathrm{mg})$ was diluted with methanol in a $50 \mathrm{~mL}$ volumetric flask to give the concentration of $100 \mathrm{ppm}$. Each extract and fraction solution was made at concentrations of 5, 10, 15, 20 and 25 ppm in a $5 \mathrm{~mL}$ volumetric flask, then added $1 \mathrm{~mL}$ of a 0.2 $\mathrm{mM}$ DPPH solution in methanol. The solution was left for 30 minutes before they were analyzed at $\lambda_{\max }$ wavelength. The $\lambda_{\max }$ wavelength was determined by measuring DPPH 100 $\mathrm{ppm}$ solution at wavelength of $800-400 \mathrm{~nm}$. Antioxidant activity was calculated using equation (3), where $\mathrm{A}=$ absorbance of the negative control and $\mathrm{B}=$ absorbance of the sample. The correlation between each concentration and its percentage of scavenging was plotted, and the $\mathrm{IC}_{50}$ was calculated by interpolation. The antioxidant activity was quantified as $\mathrm{IC}_{50}$ that represents the effective concentration of each extract which scavenges $50 \%$ of DPPH radicals.

$$
\text { Antioxidant activity }=\frac{(A-B)}{A} \times 100
$$

\section{Data analysis}

Isolated compounds were identified and analyzed using UV-Vis Spectroscopy, GC-MS and LC-MS. Total

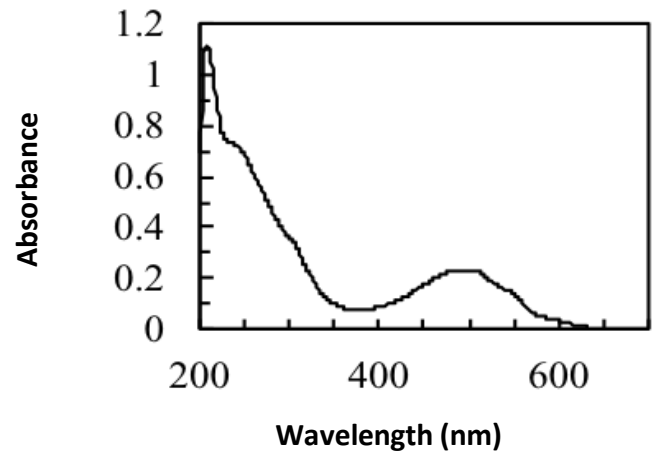

A phenolics, total anthocyanins, and antioxidant activity are shown in the form of figures that quantitatively stated their content in teak leaves.

\section{RESULTS AND DISCUSSION}

The resulting fractions from LVC were collected into four falcon tubes based on the same TLC spots using a mixture of hexane and ethyl acetate (1: 5) as eluent, which are fractions 3-5, fractions 6-8, fraction 9-20 and fractions 21-30. The fractions 3-5 and fractions 9-20 were then fractioned further by GCC. Fractionation of fractions 3-5 was completed by GCC for two times to obtain fraction A $\left(\mathrm{F}_{\mathrm{A}}\right)$. Fractionation of fraction 9-20 was also performed for two times by $\mathrm{GCC}$ to obtain fraction $\mathrm{C}\left(\mathrm{F}_{\mathrm{C}}\right)$. The UV-Vis Spectroscopy spectra of fraction $\mathrm{F}_{\mathrm{A}}$ and $\mathrm{F}_{\mathrm{C}}$ are shown in Figure 1.

The GC spectrum of fraction $F_{A}$ is presented in Figure 2 and LC-MS spectrum of fraction $\mathrm{F}_{\mathrm{C}}$ is displayed in Figure 3. Analysis of $\mathrm{GC}$ chromatogram of fraction $\mathrm{F}_{\mathrm{A}}$ revealed that this fraction contains 76 compounds. However, MS data of the fraction $F_{A}$ revealed that only 15 compounds were able to identify (Table 1).

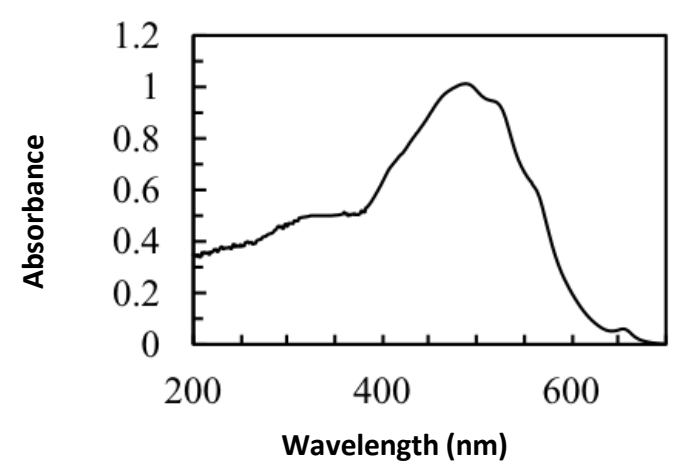

B

Figure 1. UV-Vis spectra of fraction $\mathrm{F}_{\mathrm{A}}(\mathrm{A})$ and fraction $\mathrm{F}_{\mathrm{C}}(\mathrm{B})$

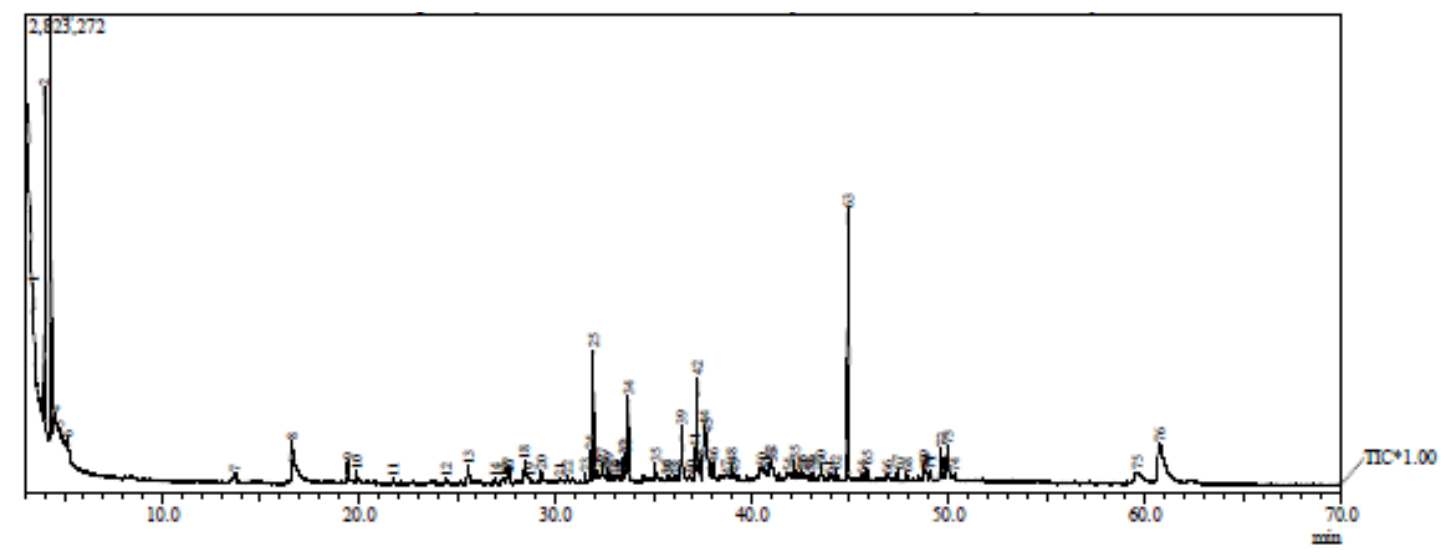


Figure 2. GC Spectrum of fraction $\mathrm{F}_{\mathrm{A}}$

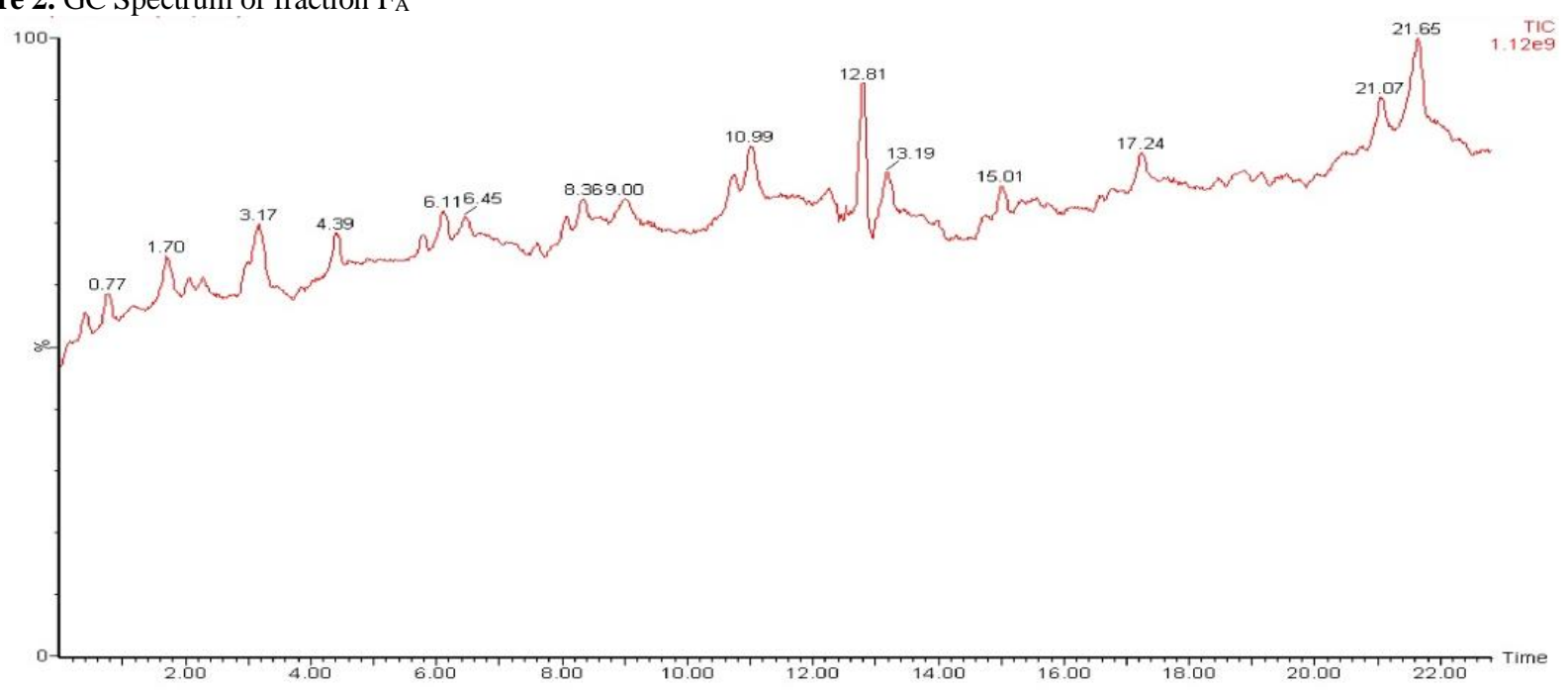

Figure 3. LC Spectrum of fraction $F_{C}$

Table 1. Identified compounds of fraction $\mathrm{F}_{\mathrm{A}}$ by GC-MS analysis.

\begin{tabular}{|c|c|c|c|c|}
\hline Retardation time (mins) & Peak number & $\%$ area & $\begin{array}{l}\text { Molecule } \\
\text { formula }\end{array}$ & Compound \\
\hline 3.433 & 1 & 1.40 & $\mathrm{C}_{6} \mathrm{H}_{12} \mathrm{O}_{6}$ & butyl acetate \\
\hline 4.008 & 2 & 8.50 & $\mathrm{C}_{6} \mathrm{H}_{12} \mathrm{O}_{2}$ & 4-hydroxy-4-methyl-2-pentanone \\
\hline 16.592 & 8 & 4.28 & $\mathrm{C}_{5} \mathrm{H}_{10} \mathrm{O}_{4}$ & Glycerin monoacetate \\
\hline 19.433 & 9 & 0.91 & $\mathrm{C}_{7} \mathrm{H}_{12} \mathrm{O}_{5}$ & glycerin diacetate \\
\hline 31.508 & 23 & 0.34 & $\mathrm{C}_{7} \mathrm{H}_{34} \mathrm{O}_{2}$ & isopropyl myristate \\
\hline 33.592 & 33 & 0.86 & $\mathrm{C}_{20} \mathrm{H}_{42} \mathrm{O}$ & 1-eicosanol \\
\hline 33.708 & 34 & 2.72 & $\mathrm{C}_{11} \mathrm{H}_{22} \mathrm{O}_{2}$ & methyl decanoate \\
\hline 35.092 & 35 & 0.56 & $\mathrm{C}_{18} \mathrm{H}_{36}$ & 1-octadecene \\
\hline 37.100 & 41 & 1.11 & $\mathrm{C}_{19} \mathrm{H}_{34} \mathrm{O}_{2}$ & 9,12-dimethyl octadecadienoate \\
\hline 37.233 & 42 & 3.81 & $\mathrm{C}_{19} \mathrm{H}_{36} \mathrm{O}_{2}$ & 11-methyl octadecenoate \\
\hline 38.975 & 48 & 0.62 & $\mathrm{C}_{16} \mathrm{H}_{33} \mathrm{Cl}$ & 1-chloro hexadecane \\
\hline 44.267 & 62 & 0.20 & $\mathrm{C}_{16} \mathrm{H}_{34}$ & hexadecane \\
\hline 47.425 & 67 & 0.34 & $\mathrm{C}_{20} \mathrm{H}_{42}$ & eicosanoid \\
\hline 48.775 & 69 & 0.50 & $\mathrm{C}_{18} \mathrm{H}_{35} \mathrm{NO}$ & 9-octadecenamide \\
\hline 48.900 & 70 & 0.36 & $\mathrm{C}_{17} \mathrm{H}_{36}$ & heptadecane \\
\hline
\end{tabular}

Table 2. Retardation time $\left(\mathrm{R}_{\mathrm{t}}\right)$ and mass-to-charge ratio $(\mathrm{m} / \mathrm{z})$ of compounds of fraction $\mathrm{F}_{\mathrm{C}}$ eluded by LC-MS.

\begin{tabular}{ccc}
\hline $\begin{array}{c}\text { Rt } \\
\text { Retardation } \\
\text { time) }\end{array}$ & $\mathbf{m} / \mathbf{z}$ & Compound \\
\hline 0.77 & 699.35 & - \\
1.70 & 700.35 & - \\
3.17 & 700.45 & - \\
4.39 & 700.35 & - \\
6.11 & 700.55 & - \\
6.45 & 697.35 & - \\
8.36 & 683.34 & petunidin-3-O- (6-O-acetyl)-5-O- \\
& & - \\
9.00 & 694.35 & - \\
10.99 & 698.35 & - \\
12.81 & 691.79 & - \\
13.19 & 698.35 & diglucoside \\
15.01 & 700.35 & diglucoside \\
17.24 & 697.35 & malvidin-3-0- (6-o-acetyl)-5-0- \\
& & \\
21.07 & 695.35 &
\end{tabular}

$21.65 \quad 700.62$

Table 3. $\mathrm{IC}_{50}$ values of the samples

\begin{tabular}{lcc}
\hline \multicolumn{1}{c}{ Sample } & IC $_{\mathbf{5 0}}(\mathbf{p p m})$ & $\begin{array}{c}\text { Antioxidant } \\
\text { activity }\end{array}$ \\
\hline Methanol extract & 21.95 & Very strong \\
Fraction $\mathrm{F}_{\mathrm{A}}$ & 29.73 & Very strong \\
Fraction $\mathrm{F}_{\mathrm{C}}$ & 32.71 & Very strong \\
Vitamin E & 24.12 & Very strong \\
\hline
\end{tabular}

Total phenolics and anthocyanins contents of teak leave methanol extract was $6.17 \mathrm{mg}$ GAE/g and $67.5 \mathrm{mg} / \mathrm{L}$, respectively. The DPPH method using methanol as solvent was applied for determination of antioxidant activity (Lung and Destiani 2017) and vitamin E was used as a positive control. The antioxidant activity of the samples was confirmed by decreasing the absorbance and changing sample solution color from purple to yellow. The 
antioxidant activity of samples was quantified as $\mathrm{IC}_{50}$ values which are presented in Table 3.

\section{Discussion}

As presented in Table 3, methanol extract, fraction $\mathrm{F}_{\mathrm{A}}$ and fraction $\mathrm{F}_{\mathrm{C}}$ had very strong antioxidant activity. The strong antioxidant activity of methanol extract was confirmed by the total phenolics and anthocyanins content of the methanol extract which is known to have strong antioxidant activities. The strong antioxidant activities of fraction $F_{A}$ and fraction $F_{C}$ were also confirmed by the presence of chemical contents of those fractions.

As shown in Fig. 1 (a), the UV-Vis spectrum of fraction $F_{A}$ has two peaks at 208 and $492 \mathrm{~nm}$. This spectrum feature was similar to the spectrum obtained by Baharuddin et al. (2015), which had two peaks at 220 and $522 \mathrm{~nm}$. The UVVis spectrum of fraction $F_{C}$ has peak at 489 nm (Fig. 1 (b)). Anthocyanins give peak at wavelength of 475-550 nm, indicating that fractions $\mathrm{F}_{\mathrm{A}}$ and $\mathrm{F}_{\mathrm{C}}$ contain anthocyanins.

As confirmed by GC-MS analysis, fraction $\mathrm{F}_{\mathrm{A}}$ contains alkanes (namely hexadecane, 1-chloro hexadecane, heptadecane, and eicosanoid), alkene (namely 1octadecene), alcohol (namely 1-eicosanol), ketone (4hydroxy-4-methyl-2-pentanone), esters (namely butyl acetate, isopropyl myristate, methyl decanoate, 11-methyl octadecenoate, 9,12-dimethyl octadecadienoate), amide (namely 9-octadecenamide) and glycerin (namely glycerin monoacetate and glycerin diacetate). These compounds mostly have chromophore groups that give specific colors (Qadariyah et al. 2018) and the color of fraction $F_{A}$ was orange. Yet, no anthocyanins in fraction $\mathrm{F}_{\mathrm{A}}$ were detected by GC-MS analysis because the GC column temperature was $300^{\circ} \mathrm{C}$, while anthocyanin's boiling point was more than $300^{\circ} \mathrm{C}$. Among those 15 compounds of fractions $F_{A}, 4$ compounds have $\mathrm{OH}$ groups on their structure which cause antioxidant activity of fraction $\mathrm{F}_{\mathrm{A}}$. They are 4-hydroxy-4methyl-2-pentanone (1), glycerin monoacetate (2), glycerin diacetate (3) and 1-eicosanol (4). These compounds force together to reduce free radicals. Murukan and Murugan (2018c) reported that methanolic leaf extracts of young and mature leaf of $T$. grandis has phenolic compounds such as gallic, vanillic, $p$-hydroxybenzoic, ferulic, chlorogenic, sinapic, $p$-coumarate, and cinnamic acids.

The LC-MS analysis of fraction $\mathrm{F}_{\mathrm{C}}$ revealed 15 peaks. Two compounds having retention time of 8.36 and 17.24 minutes were able to be identified. The compound which was eluded at 8.36 minutes had $\mathrm{m} / \mathrm{z} 683.34$ and was classified as secondary metabolite of anthocyanin, namely petunidin-3-O- (6-O-acetyl)-5-O-diglucoside (5) (Figure 3) Han et al. (2017). The second compound had $\mathrm{m} / \mathrm{z}$ of 697.35 and was also classified as secondary metabolite of anthocyanin, namely malvidin-3-o- (6-o-acetyl)-5-odiglucoside (6) (Figure 4). This result is in accordance with the research of De la Cruz et al. (2012) and Han et al. (2017) that malvidin-3-o- (6-o-acetyl)-5-o-diglucoside (6) was determined at a retention time of 18 minutes according to LC-MS result. These anthocyanins have $\mathrm{OH}$ groups, heterocyclic rings and conjugated double bonds in its structure that provide very strong antioxidant activity. In conclusion, the research showed that the teak leaves have active compounds which strong antioxidant activities.<smiles>CC(=O)CC(C)(C)O</smiles>

1<smiles>CC(=O)OCC(O)CO</smiles>

2<smiles>CC(=O)OCC(CO)OC(C)=O</smiles><smiles>CCCCCCCCCCCCCCCCCCCCO</smiles>

4<smiles>COc1cc(-c2[o+]c3cc(O)cc(OC4O[C@H](CO)[C@@H](O)[C@H](O)[C@H]4O)c3cc2OC2O[C@H](COC(C)=O)[C@@H](O)[C@H](O)[C@H]2O)cc(O)c1O</smiles><smiles>COc1cc(-c2[o+]c3cc(O)cc(OC4O[C@H](CO)[C@@H](O)[C@H](O)[C@H]4O)c3cc2OC2O[C@H](COC(C)=O)[C@@H](O)[C@H](O)[C@H]2O)cc(OC)c1O</smiles> 
Figure 4. Identified compounds which cause antioxidant activity

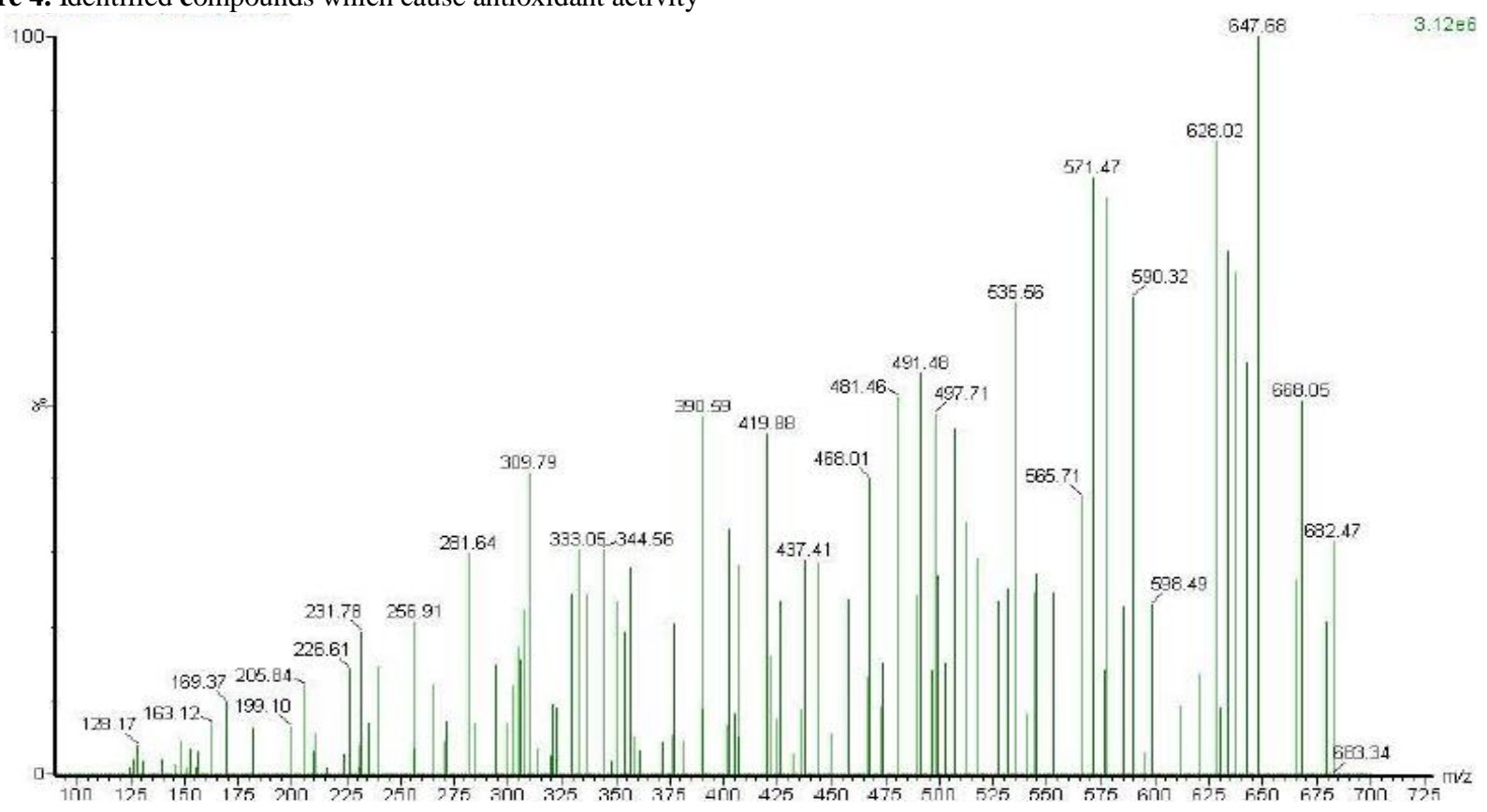

Figure 5. MS data of the compound with retention time of 8.36 minute

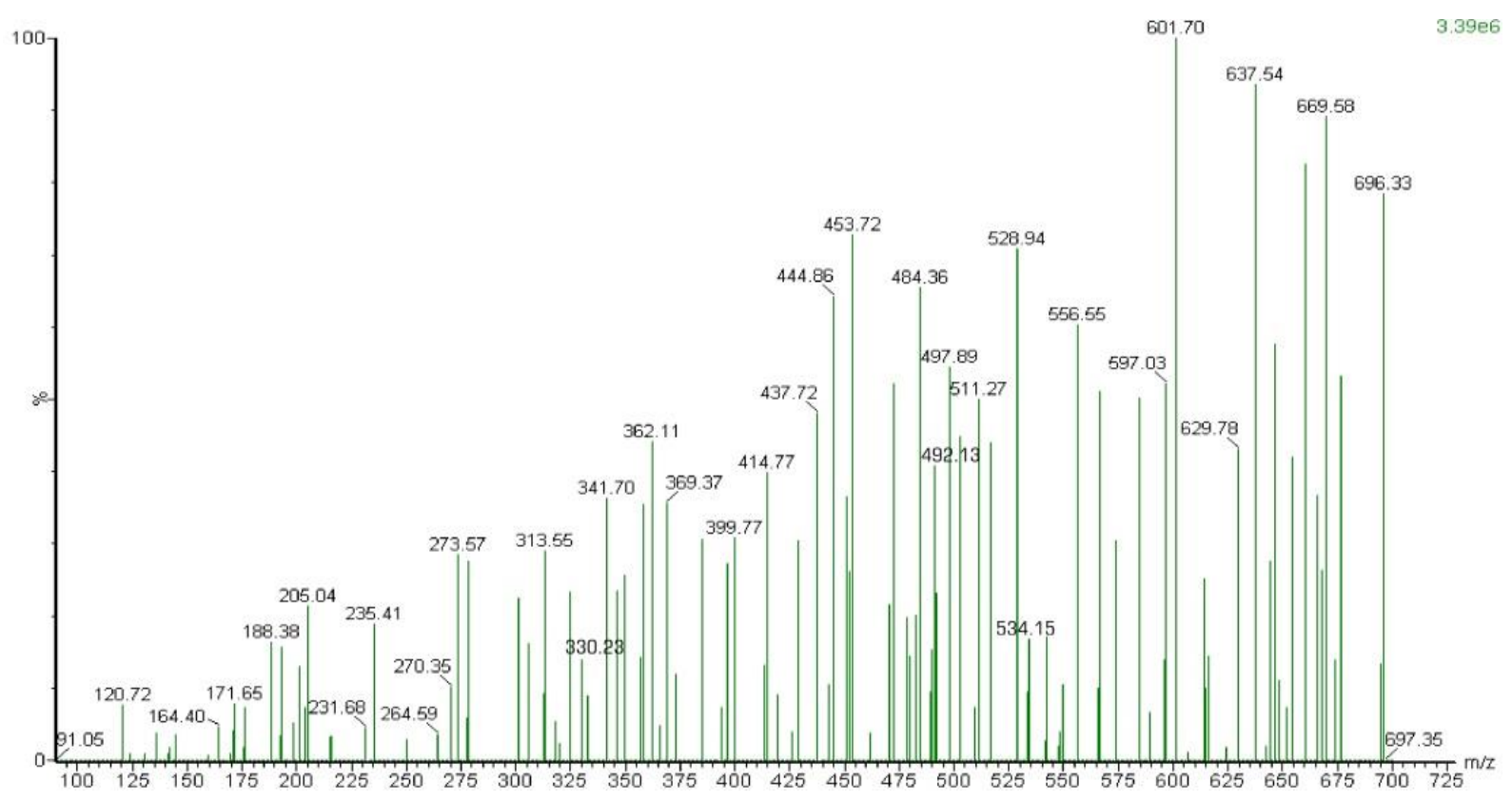

Figure 6. MS data of the compound with retention time of 17.24 minute

\section{ACKNOWLEDGEMENTS}

We thank Sebelas Maret University, Indonesia for financial support of this research with grant number: 516/UN27.21/PP/2019.
REFERENCES

Arief II, Suryati T, Afiyah DN, Wardhani DP. 2014. Physicochemical and organoleptic of beef sausages with teak leaf extract (Tectona grandis) addition as preservative and natural dye. Int Food Res J 21 (5): 20332042. 
Baharuddin A, Aisyah, Saokani J, Risnah IA. 2015. Karakterisasi zat warna daun jati (Tectona grandis) fraksi metanol: n-heksana sebagai photosensitizer pada dye sensitized solar cell. Chimica et Natura Acta 3 (1): 37-41. [Indonesian]

De La Cruz AA, Hilbert G, Riviere C, Mengin V, Ollat N, Bordenave L, Decroocq S, Delaunay J, Delrot S, Merillon J, Monti J, Gomes E, Richard T. 2012. Anthocyanin identification and composition of wild Vitis spp. Accessions by using LC-MS and LC-NMR. Anal Chim Acta 732: 145-152.

Doymaz I, Karasu S. 2018. Effect of air temperature on drying kinetics, colour changes and total phenolic content of sage leaves (Salvia officinalis). Qual Assurance Saf Crops Foods 10 (3): 269-276.

Du H, Wu J, Ji K, Zeng Q, Bhuiya M, Su S, Shu Q, Ren H, Liu Z, Wang L. 2015. Methylation mediated by an anthocyanin, Omethyltransferase, is involved in purple flower coloration in Paeonia. J Exp Bot 66 (21): 6563-6577.

Ghany TMA. 2015. Safe food additives: a review. J Chem Biol Res 32 (1): 402-437

Han F, Ju Y, Ruan X, Zhao X, Yue X, Zhuang X, Qin M, Fang Y. 2017. Color, anthocyanin, and antioxidant characteristics of young wines produced from spine grapes (Vitis davidi Foex) in China. Food Nutr Res 61 (1): 1-11.

Hanani E, Mun'im A, Sekarini R. 2005. Identifikasi senyawa antioksidan dalam spons Callyspongia sp. dari Kepulauan Seribu. Majalah Ilmu Kefarmasian 2 (3): 127-133. [Indonesian]

Hermawati Y, Rofieq A, Wahyono P. 2015. Influence of citric acid concentrate to characteristic of teak leaf anthocyanin extract with its stability test in ice cream. Prosiding Seminar Nasional Pendidikan Biologi 2015. Universitas Muhammadiyah Malang. 21 Maret 2015 [Indonesian]

Kopa TK, Tchinda AT, Tala MF, Zofou D, Jumbam R, Wabo HK, Titanji VPK, Frederich M, Tan N, Tane P. 2014. Antiplasmodial anthraquinones and hemisynthetic derivatives from the leaves of Tectona grandis (Verbenaceae). Phytochem Lett 8: 41-45.

Kutlu T, Durmaz G, Ates B, Yilmaz I, Cetin MS. 2011. Antioxidant properties of different extracts of black mulberry (Morus nigra L.). Turk J Biol 35: 103-110.
Lee J, Durst RW, Wrolstad RE. 2005. Determination of total monomeric anthocyanin pigment content of fruit juices, beverages, natural colorants, and wines by the $\mathrm{pH}$ differential method: collaborative study. J AOAC Int 88 (5): 1269-1278.

Lismawenning D, Yulianto A, Sulhadi. 2013. Aplikasi ekstrak daun jati (Tectona grandis) sebagai film kaca non permanen. Unnes Phys J 2 (1): 51-57. [Indonesian]

Lung JKS, Destiani DP. 2017. Uji aktivitas antioksidan vitamin A, C, E dengan metode DPPH. Farmaka 15 (1): 53-62. [Indonesian]

Murukan G, Murugan K. 2017. Composition of purified anthocyanin isolated from teak and it's in vitro antioxidant activity. Int J Pharm Pharm Sci 9 (9): 258-266.

Murukan G, Murugan K. 2018a. Hepatoprotective activity of purified anthocyanin from teak leaves against CCL-4 induced hepatotoxicity in wistar albino rats and its analysis by LC-MS/MS. J Glob Trends Pharm Sci 9 (2): 5244-5260.

Murukan G, Murugan K. 2018b. Antimutagenic efficacy of purified anthocyanin from the in vitro culture of teak leaves on $b$ marrow cells of mice. Intl J Phar Bio Sci 9 (3): 38-46.

Murukan G, Murugan K. 2018c. Comparison of phenolic acids and antioxidant activities of young and mature leaves of Tectona grandis L F. Asian J Pharm Clini Res 11 (1): 60-66.

Ogunmefun OT, Ekundayo EA, Akharaiyi FC, Ewhenodere D. 2017. Phytochemical screening and antibacterial activities of Tectona grandis L.f. teak leaves on microorganisms isolated from decayed food samples. J Trop Plant Res 4 (3): 376-382.

Qadariyah L, Mahfud M, Sulistiawati E, Swastika P. 2018. Natural dye extraction from teak leaves (Tectona grandis) using ultrasoundassisted extraction method for dyeing on cotton fabric. MATEC Web of Conferences 156: 1-4.

Rajuri A, Rao KNV, Banji D, Chaithanya RK. 2010. A review on Tectona grandis Linn: chemistry and medicinal uses (famili: Verbenaceae). Herbal Tech Ind 1: 6-9.

Salazar-Aranda R, Perez-Lopez LA, Lopez-Arroyo, Alanis-Garza BA, de Torres NW. 2011. Antimicrobial and antioxidant activities of plants from northeast of Mexico. Evidence-Based Complement Altern Med 2011 (536139): 1-6 